\title{
APLIKASI BERBAGAIJENIS PUPUK ORGANIK CAIR TERHADAP PERTUMBUHANDAN PRODUKSI EMPAT VARIETAS TANAMAN KACANGHIJAU(Vigna radiata. $\mathrm{L}$ )
}

\section{Application of Various Types of Liquid Organic Fertilizers Against Growth and Production of Four Green Bean Plant Varieties (Vigna radiata. L)}

\author{
Parlinggoman Sinaga, Maizar, Fathurrahman \\ Fakultas Pertanian Universitas Islam Riau \\ Jl. Khaharuddin Nasution No. 113 Pekanbaru. 28284 \\ Telp: 0761-674681 ; Fax: 0761-674681 \\ [Diterima: Juli 2017; Disetujui: Desember 2017]
}

\begin{abstract}
The purpose of this study was to determine the interaction and main effects of various types of liquid organic fertilizer on the growth and production of four varieties of green bean plants. This study uses a factorial Randomized Complete Design. The first factor is a variety of liquid organic fertilizer (C) consisting of 4 levels, while the second factor is a variety of green bean varieties (V) consisting of 4 levels. Of these two factors, there are 16 combinations of treatments with 3 replications. Then there are 48 experimental units. Each unit consists of 15 plants. The parameters observed were as follows: plant height and flowering age. Data from observations from each treatment were analyzed statistically and continued with a further test of Honest Real Difference (BNJ) at the level of 5\%. The results showed that both the interaction and the main influence of giving liquid fertilizer to various varieties influenced plant height and flowering age. Interactively, the best treatment was in the administration of POMI $4 \mathrm{cc} / 1$ in varieties of the Murai variety (C2V4). Singularly the best treatment for POMI $4 \mathrm{cc} / 1$ (C2) in the best variety is Walnuts (V1).
\end{abstract}

Keywords: Liquid organic fertilizer, Varieties and Green Bean.

\begin{abstract}
ABSTRAK
Tujuan penelitian ini adalah untuk mengetahui interaksi dan pengaruh utama berbagai jenis pupuk organik cair terhadap pertumbuhan dan produksi empat varietas tanaman kacang hijau.Penelitian ini menggunakan Rancangan Acak Lengkap (RAL) faktorial. Faktor pertama adalah berbagai pupuk organik cair (C) terdiri dari 4 taraf, sedangkan faktor kedua adalah berbagai varietas kacang hijau (V) yang terdiri 4 taraf. Dari dua faktor tersebut, terdapat 16 kombinasi perlakuan dengan 3 kali ulangan.Maka terdapat 48 unit percobaan.Tiap satuan unit terdiri dari 15 tanaman.Parameter yang diamati sebagai berikut: tinggi tanaman dan umur berbunga. Data hasil pengamatan dari masing-masing perlakuan dianalisis secara statistik dan di lanjutkan dengan uji lanjut Beda Nyata Jujur (BNJ) pada taraf 5\%. Hasil penelitian menunjukan bahwa baik secara interaksi maupun pengaruh uatma pemberian jenis pupuk cair pada berbagai varietas memberikan pengaruh terhadap tinggi tanaman dan umur berbunga. Secara interaksi perlakuan terbaik pada pemberian POMI $4 \mathrm{cc} / 1$ pada varietas varietas Murai $\left(\mathrm{C}_{2} \mathrm{~V}_{4}\right)$. Secara tunggal perlakuan terbaik pada pemberian POMI $4 \mathrm{cc} / \mathrm{l}\left(\mathrm{C}_{2}\right)$ pada varietas terbaik adalah Kenari $\left(\mathrm{V}_{1}\right)$.
\end{abstract}

Kata kunci:Pupuk organik cair, Varietas dan Kacang Hijau

\section{PENDAHULUAN}

Kacang hijau (Vigna radiata. L) merupakan salah satu komoditas tanaman kacang-kacangan golongan Leguminosa yang memiliki nilai gizi dan ekonomis penting 
setelah tanaman kacang tanah dan kacang kedelai. Sampai saat ini perhatian masyarakat terhadap kacang hijau masih kurang.Hal ini disebabkan oleh hasil yang dicapai oleh petani perhektarnya masih rendah.

Manfaat kacang hijau sebagai makanan rakyat sangat penting karna jenis kacang ini banyak mengandung vitamin, terutama vitamin B1, zat ini sangat diperlukan karna merupakan tambahan berharga bagi makanan rakyat yang relative kurang vitamin. Disamping sebagai bahan makanan, kacang ini juga dapat digunakan sebagai pakan ternak, dari beberapa manfaat inilah terasa pentingnya memopulerkan tanaman kacang hijau.

Unsur hara yang dibutuhkan tanaman sebagai sumber makanan tidak selamanya ada didalam tanah, karena itu perlu dilakukan penambahan unsur hara dari luar yaitu dengan jalan pemupukan.Pemupukan dimaksud adalah memberikan unsur hara pada tanaman baik melalui tanah maupun organ luar bagian tanaman.Pemberian pupuk an-organik secara terus menerus dapat mengakibatkan produktivitas lahan menurun. Salah satu cara untuk mengatasi hal ini adalah dengan pemberian pupuk organik.

Salah satu alternatif untuk mempertahankan dan meningkatkan hasil tanaman kacang hijau adalah dengan pemberian pupuk organik cair. Pupuk organik cair tidak menimbulkan efek negatif terhadap jaringan tanaman karena bahan dasarnya alamiah, sehingga mudah diserap secara menyeluruh oleh tanaman. Pupuk organik cair pada umumnya mengandung unsur hara makro dan mikro esensial (N, P, K, S, Ca, Mg, B, Mo, Cu, $\mathrm{Fe}, \mathrm{Mn}$, dan bahan organik). Pupuk organik cair mempunyai beberapa manfaat diantaranya dapat mendorong dan meningkatkan pembentukan klorofil daun dan pembentukan bintil akar pada tanaman leguminosa sehingga meningkatkan kemampuanfotosintesis tanaman dan menyerap nitrogen dari udara (Hamli et al.,, 2010).

Pupuk organik cair sangat berperan besar dalam usaha memperbaiki sifat-sifat tanah yaitu secara fisik, kimia dan biologi tanah, mampu mempercepat pertumbuhan vegetatif pada tanaman dan memberikan dampak positif bagi pertumbuhan tanaman. Dengan pemberian pupuk organik cairakan mampu meningkatkankesuburan tanah dan memperbaiki sifat tanah sehingga pertumbuhan dan hasil tanaman Kacang hijau meningkat (Mulyani, 2013).

Pupuk organik cair adalah hasil proses fermentasi bahan-bahan organik yang berasal dari sisa tanaman, kotoran hewan dan manusia yang kandungan unsur haranya lebih dari satu unsur. Kelebihan dari pupuk organik ini adalah mampu mengatasi defisiensi hara secara cepat, tidak bermasalah dalam pencucian hara, dan juga mampu menyediakan hara secara cepat.Jika dibandingkan dengan pupuk anorganik, pupuk organik cair umumnya tidak merusak tanah dan tanaman meskipun sudah digunakan sesering mungkin.Selain itu, pupuk ini juga memiliki bahan pengikat sehingga larutan pupuk yang diberikan ke permukaan tanah bisa langsung dimanfaatkan oleh tanaman (Hadisuwito, 2012).

Varietas memegang peranan penting dalam perkembangan penanaman, karena untuk mencapai produktivitas yang tinggi sangat di tentukan oleh potensi daya hasil dari varietas unggul yang ditanam.Potensi hasil dilapangan dipengaruhi pula oleh interaksi antara faktor genetik varietas dengan kondisi lingkungan tumbuh.Bila pengelolaan lingkungan tumbuh tidak dilakukan dengan baik, potensi daya hasil yang tinggi dari varietas unggul tersebut tidak dapat tercapai. Suatu varietas dapat dilihat keunggulannya dari sifat yaitu memiliki potensi hasil tinggi 1,5-2,0 ton/ha, umur tanaman kurang dari 90 hari, mutu biji dihasilkan yang baik (seragam), tahan rebah serta tahan dari gangguan hama dan penyakit (Adisarwanto, 2005).

Saat ini banyak macam varietas kacang hijau unggul hasil pemuliaan yang dilepaskan untuk dikembangkan. Tanaman kacang hijau memiliki beberapa varietas unggul, diantaranya yaitu : varietas Kenari, varietas Vima-1, varietas Sriti dan varietas Murai, merupakan varietas kacang hijau yang banyak digunakan saat ini memiliki potensi hasil yang cukup baik. Berdasarkan uraian diatas, maka penulis telahmelakukan penelitian dengan judul "Aplikasi Berbagai Jenis Pupuk Organik Cair Terhadap Pertumbuhan Dan ProdukisiEmpat Varietas Tanaman Kacang Hijau (Vigna radiata. $\mathrm{L})$. 


\section{METODE PENELITIAN}

Penelitian ini telah dilaksanakan di Kebun Percobaan Fakultas Pertanian Universitas Islam Riau, Jalan Kaharudin Nasution KM 113, Kelurahan Air Dingin, Kecamatan Bukit Raya Kota Pekanbaru. Penelitian ini dilaksnakan selama 4 bulan terhitung dari bulan Maret - Juni 2017.

Bahan yang digunakan dalam penelitian ini adalah pupuk Hantu, pupuk Pomi, pupuk POC Nasa, pupuk Herbafarm, benih Varietas Kenari, Vima-1, Sriti, Murai,NPK (16:16:16), curater 3G, Decis 25 EC dan Dithen-45. Sedangkan Alat yang digunakan dalam penelitian ini adalah Cangkul, Pisau Kater, Garu, Sabit, Gembor, Hand Sprayer, Meteran, Martil, Paku, Timbangan, Tali Rafia, Kamera, dan Alat-alat Tulis.

Penelitian ini menggunakan Rancangan Acak Lengkap (RAL) factorial. Faktor pertama adalah berbagai pupuk organik cair (C) terdiri dari 4 taraf, sedangkan faktor kedua adalah berbagai varietas kacang hijau (V) yang terdiri 4 taraf. Dari dua faktor tersebut, terdapat 16 kombinasi perlakuan dengan 3 kali ulangan.Maka terdapat 48 unit percobaan. Tiap satuan unit terdiri dari 15 tanaman, dan 2 diantaranya dijadikan sampel, sehingga jumlah keseluruhan berjumlah 720 tanaman.
1. Faktor pemberian berbagai pupuk organik cair (C) yaitu :

$\mathrm{C}_{1}$ : Pemberian Pupuk Hantu 4cc/l air

$\mathrm{C}_{2}$ : Pemberian Pupuk Pomi $4 \mathrm{cc} / \mathrm{l}$ air

$\mathrm{C}_{3}$ :Pemberian Pupuk POC Nasa $4 \mathrm{cc} / \mathrm{l}$ air

$\mathrm{C}_{4}$ : Pemberian Pupuk Herbafarm $4 \mathrm{cc} / \mathrm{l}$ air

2. Faktor varietas kacang hijau (V) yaitu:

$\mathrm{V}_{1}$ : Varietas Kenari

$\mathrm{V}_{2}$ : Varietas Vima-1

$\mathrm{V}_{3}$ : Varietas Sriti

$\mathrm{V}_{4}$ : Varietas Murai

Data pengamatan terahir, dari masingmasing perlakuan dianalisis secara statistik. Jika $\mathrm{F}$ hitung lebih besar dari $\mathrm{F}$ tabel dilakukan Uji lanjut beda nyata jujur (BNJ) pada taraf $5 \%$.

\section{HASIL DAN PEMBAHASAN}

\section{Tinggi Tanaman (cm)}

setelah $\begin{aligned} & \text { pengamatan tinggi tanala } \\ & \text { dilakukan analisis }\end{aligned}$ ragam.memperlihatkan bahwa secara interaksi maupun pengaruh utama pupuk cair dan varietas berpengaruh nyata terhadap tinggi tanaman kacang hijau. Rerata hasil pengamatan terhadap tinggi tanaman dapat di lihat pada Tabel 1 .

Tabel 1.Rerata tinggi tanaman kacang hijau dengan perlakuan Jenis pupuk cair dan Jenis varietas $(\mathrm{cm})$.

\begin{tabular}{|c|c|c|c|c|c|}
\hline \multirow{2}{*}{$\begin{array}{c}\text { Jenis pupuk } \\
\text { (cc/l air) }\end{array}$} & \multicolumn{4}{|c|}{ Jenis varietas } & \multirow[b]{2}{*}{ Rerata } \\
\hline & Kenari $\left(\mathrm{V}_{1}\right)$ & Vima-1 $\left(\mathrm{V}_{2}\right)$ & $\operatorname{Sriti}\left(V_{3}\right)$ & Murai $\left(\mathrm{V}_{4}\right)$ & \\
\hline Puhan $\left(\mathrm{C}_{1}\right)$ & $51,00 \mathrm{~cd}$ & $50,67 \mathrm{~cd}$ & $54,33 \mathrm{bcd}$ & $49,67 \mathrm{~cd}$ & $51,42 \mathrm{~b}$ \\
\hline Pomi $\left(\mathrm{C}_{2}\right)$ & $51,00 \mathrm{~cd}$ & $55,00 \mathrm{bc}$ & $61,00 \mathrm{a}$ & $49,00 \mathrm{~d}$ & $54,00 \mathrm{a}$ \\
\hline POC Nasa $\left(\mathrm{C}_{3}\right)$ & $50,67 \mathrm{~cd}$ & $51,33 \mathrm{~cd}$ & $59,00 \mathrm{ab}$ & $50,33 \mathrm{~cd}$ & $52,83 \mathrm{ab}$ \\
\hline Herbafarm $\left(\mathrm{C}_{4}\right)$ & $51,33 \mathrm{~cd}$ & $53,00 \mathrm{~cd}$ & $52,67 \mathrm{~cd}$ & $50,67 \mathrm{~cd}$ & $51,92 \mathrm{ab}$ \\
\hline \multirow[t]{2}{*}{ Rerata } & $51,00 \mathrm{bc}$ & $52,50 \mathrm{~b}$ & $56,75 \mathrm{a}$ & $49,92 \mathrm{c}$ & \\
\hline & $\mathrm{KK}=3,65 \%$ & $\mathrm{BNJ} C V=5,84$ & $\mathrm{BN}$ & $C \& V=2,13$ & \\
\hline
\end{tabular}

Pada Tabel 1 menunjukkan bahwa secara interaksi pemberian jenis pupuk cair dan jenis varietas memberikan pengaruh yang berbeda nyata terhadap tinggi tanaman kacang hijau, dengan perlakuan terbaik pemberian POMI 4 cc/l air dan varietas sriti $\left(\mathrm{C}_{2} \mathrm{~V}_{3}\right)$ dengan tinggi tanaman $61,00 \mathrm{~cm}$. Ini disebabkan pemberian pupuk cair POMI mampu memperbaiki sifat fisik dan kimia tanah lebih baik, sehingga memberikan pertumbuhan perakaran yang baik. Selain itu, juga dikarenakan penyerapan hara $\mathrm{P}$ yang diberikan pada tanaman terpenuhi dengan optimal, akibat baiknya pertumbuhan perakaran 
tanaman. Hal ini sesuai dengan pendapat Soemartonoet al.,(1980) dalam Sutedjo (2002) yang mengemukakan bahwa pupuk fosfor dibutuhkan tanaman untuk merangsang pembentukan akar, mempercepat tumbuhnya tanaman, menstimulir pembungaan dan pembentukan buah serta mempercepat panen. Rinsema (2004) mengemukakan tanaman yang kekurangan unsur $\mathrm{P}$ warna daun menjadi hijau tua, kadang-kadang menjadi warna ungu, pertumbuhan terhambat dan batangnya menjadi kerdil, pembentukan biji terhambat.

Unsur fosfor ini dapat dimanfaatkan oleh tanaman pada pertumbuhan awal yaitu dalam proses pembentukan akar dengan terpenuhinya unsur fosfor maka dapat membentuk akar yang lebih banyak sehingga tanaman dapat lebih banyak menyerap unsur hara dengan demikian akan memacu pertumbuhan titik tumbuh tanaman. Lingga (1998) dalam Isroi (2008) mengemukakan bahwa unsur hara $\mathrm{P}$ berguna untuk merangsang pertumbuhan akar.Penyusunan lemak dan protein.Untuk mendapatkan efisiensi pemupukan yang optimal, pupuk harus diberikan dalam jumlah yang cukup sesuai dengan kebutuhan tanaman.

Hal ini juga dapat disebabkan unsur-unsur yang terdapat pada pupuk cair POMI yang di butuhkan untuk dapat menyuplai hara yang dibutuhkan tanaman agar dapat tumbuh dengan baik, selain itu juga dikarenakan POMI memiliki kandungan hara $\mathrm{N}$ yaitu: $\mathrm{N} 20 \%$, sebagai pembentukan protein. Sehingga dengan aplikasi pada tanaman lebih menghasilkan pertumbuhan dan perkembangan tanaman yang lebih baik(Suryadi,2017).Sehingga penambahan unsur $\mathrm{N}$ melalui pemupukan tidak terlihat.Selanjutnya Munir(2006) menjelaskan bahwa unsur nitrogen bermanfaat untuk pertumbuhan vegetative tanaman yaitu pembentukan sel-sel baru seperti daun, cabang, dan mengganti sel-sel yang rusak.Suryadi (2017) menyemukakakan apabila tanaman kekurangan unsur $\mathrm{N}$ tanaman akan memperlihatkan pertumbuhan yang kerdil.

Pada Tabel 1 terlihat bahwa pengaruh utama perlakuan jenis pupuk cair memberikan pengaruh utama terhadap tinggi tanaman, dimana perlakuan terbaik pada pemberian Pomi $4 \mathrm{cc} / \mathrm{l}$ air (C2) dengan tinggi tanaman $54,00 \mathrm{~cm}$. ini disebabkan kandungan hara yang dimiliki pupuk cair Pomi mampu memenuhi kebutuhan hara pada tanaman.

Pada Tabel 1 terihat bahwa pengaruh utama perlakuan jenis varietas memberikan pengaruh yang berbeda nyata terhadap tinggi tanaman dimana varietas Sriti (V3) menghasilkan tinggi tanaman lebih baik dibandingkan dengan varietas lainnya yaitu $56,75 \mathrm{~cm}$. ini disebabkan adaptasi tanaman terhadap lingkungan dan perlakuan yang diberikan.

\section{Umur Berbunga (Hari)}

Hasil pengamatan umur berbunga setelah dilakukan analisis ragammemperlihatkan bahwa secara interaksi maupun pengaruh utama Jenis pupuk cair dan Jenis varietas berpengaruh nyata terhadap umur berbunga tanaman kacang hijau. Rerata hasil pengamatan terhadap umur berbunga dapat di lihat pada Tabel 2 .

Tabel 2. Rata-rata umur berbunga tanaman kacang hijau dengan perlakuan Jenis pupuk cair dan jenis varietas (hari)

\begin{tabular}{|c|c|c|c|c|c|}
\hline \multirow{2}{*}{$\begin{array}{l}\text { Jenis pupuk } \\
\text { (cc/l air) }\end{array}$} & \multicolumn{4}{|c|}{ Jenis varietas } & \multirow[b]{2}{*}{ Rerata } \\
\hline & Kenari $\left(\mathrm{V}_{1}\right)$ & Vima-1 $\left(\mathrm{V}_{2}\right)$ & $\operatorname{Sriti}\left(\mathrm{V}_{3}\right)$ & Murai $\left(\mathrm{V}_{4}\right)$ & \\
\hline Puhan $\left(\mathrm{C}_{1}\right)$ & $34,67 \mathrm{~d}$ & $33,96 \mathrm{~cd}$ & $34,04 \mathrm{~cd}$ & $34,26 \mathrm{~d}$ & $34,23 \mathrm{ab}$ \\
\hline $\operatorname{Pomi}\left(\mathrm{C}_{2}\right)$ & $34,67 \mathrm{~d}$ & $30,00 \mathrm{a}$ & $34,04 \mathrm{~cd}$ & $34,50 \mathrm{~d}$ & $33,30 \mathrm{a}$ \\
\hline POC Nasa $\left(\mathrm{C}_{3}\right)$ & $34,33 \mathrm{~d}$ & $33,07 \mathrm{c}$ & $34,56 \mathrm{~d}$ & $33,67 \mathrm{~cd}$ & $33,91 \mathrm{ab}$ \\
\hline Herbafarm $\left(\mathrm{C}_{4}\right)$ & $34,11 \mathrm{~cd}$ & $32,41 \mathrm{~b}$ & $34,33 \mathrm{~d}$ & $34,67 \mathrm{~d}$ & $33,88 \mathrm{~b}$ \\
\hline \multirow[t]{2}{*}{ Rerata } & $34,44 \mathrm{~b}$ & $32,36 \mathrm{a}$ & $34,24 \mathrm{~b}$ & $34,27 \mathrm{~b}$ & \\
\hline & $\mathrm{KK}=2,06 \%$ & $\mathrm{BNJ} \mathrm{CV}=$ & $\mathrm{BNJ}$ & $\& V=0,77$ & \\
\hline
\end{tabular}

Angka-angka pada baris dan kolom yang diikuti huruf kecil yang sama menunjukan tidak berbeda nyata menurut uji lanjut BNJ pada taraf $5 \%$

Pada Tabel 2 menunjukkan bahwa secara interaksi pemberian jenis pupuk cair dan jenis varietas memberikan pengaruh yang berbeda nyata terhadap umur berbunga tanaman kacang hijau, dimana umur berbunga tercepat pada perlakuan pemberian POMI $4 \mathrm{cc} / \mathrm{l}$ dan varietas 
Vima-1 $\left(\mathrm{C}_{2} \mathrm{~V}_{2}\right)$ dengan umur berbunga 30,00 hari. Ini dikarenakan unsur hara $\mathrm{P}$ yang diberikan melalui aplikasi POMI mampu diserap akar tanaman dengan optimal, sehingga menghasilkan umur berbunga lebih cepat dibandingkan dengan perlakuan lainnya. Anonimus (2012) mengemukakan- bahwa unsur hara fospor berperan dalam proses fotosintesis, pembentukan karbohidrat dan sejumlah proses kehidupan lainnya pada tanaman. Sutedjo dan Sapoetra (1987) mengemukakan bahwa unsur hara fosfor merupakan bahan pembentuk inti sel, selain itu mempunyai peran untuk pembelahan sel serta bagi perkembangan jaringan meristematik. Fosfor dapat membentuk ikatan fospor berdaya tinggi yang digunakan untuk mempercepat proses pembungaan. Selain akan unsur hara $\mathrm{P}$ pada POMI juga terdapat unsur Nitrogen, yang juga dibutuhkan tanaman. Nitrogen merupakan unsur hara utama bagi pertumbuhan tanaman yaitu pada umumnya diperlukan pada pertumbuhan tanaman, apabila unsur Nitrogen lebih banyak maka proses pembungaan dan pembuahan akan terhambat, pupuk cair POMI merupakan pupuk lengkap yang mengandung unsur hara makro Kalium yang berfungsi sebagai katalisator enzim pada tanaman, yang dibutuhkan tanaman yang memberikan keseimbangan pertumbuhan dan perkembangan tanaman (Sutejo, 2010).

Lebih cepatnya umur berbunga pada perlakuan $\mathrm{C}_{2} \mathrm{~V}_{2}$ dibandingkan dengan perlakuan lainnya ini dikarenakan pupuk cair POMI yang diberikan mampu memberikan tingkat kesuburan tanah yang baik dan didukung dengan kandungan unsure hara $\mathrm{P}$ yang lebih banyak, sehingga mampu memberikan kebutuhan nutrisi yang lebih optimal dibandingkan dengan perlakuan lainnya.

Harjadi (1991) dalam Suhartono (2006) mengemukakan bahwa karbohidrat sangat dibutuhkan untuk pertumbuhan vegetatif dan generatif tanaman dimana karbohidrat dapat digunakan untuk pertumbuhan batang, daun, perakaran dan juga berguna untuk pertumbuhan bunga, buah dan biji.Unsur hara yang dibutuhkan tanaman pada fase generatif ialah unsur $\mathrm{P}$, yang berperan dalam pembentukan bunga dan buah. Jika kebutuhan unsur $\mathrm{P}$ terpenuhi secara maksimal, maka proses pembungaan dan pembuahan akan semakin cepat.

Rinsema (2004) mengemukakan bahwa fospor berguna untuk membentuk akar, sebagai bahan dasar protein, mempercepat penuaan buah, memperkuat batang tanaman, serta meningkatkan hasil biji-bijian dan umbiumbian.

Pada Tabel 2 menunjukkan bahwa pengaruh utama perlakuan jenis pupuk cair memberikan pengaruh yang berbeda nyata terhadap umur berbunga tanaman, dimana umur berbunga cepat pada perlakuan Pomi $4 \mathrm{cc} / \mathrm{l}$ air yaitu 33,30 hari (C2) perlakuan ini berbeda nyata dengan perlakuan lainnya. ini disebabkan kandungan hara pada Pomi mampu meningkatkan fase pertumbuhan generative tanaman yang ditandai dengan cepatnya umur berbunga pada tanaman.

Pada Tabel 2 menunjukkan bahwa pengaruh utama perlakuan jenis varietas menunjukkan pengaruh yang berbeda nyata terhadap umur berbunga tanaman, dimana umur berbunga cepat pada perlakuan varietas Vima-1 (V2) yaitu 32,36 hari. Perlakuan ini berbeda nyata dengan perlakuan lainnya.ini disebabkan jenis varietas yang berbeda menghasilkan umur berbunga yang berbeda pula, ini berkaitan dengan keungulan dari masing-masing varietas.

\section{KESIMPULAN}

Dari hasil penelitian yang telah dilakukan dapat mengambil kesimpulan sebagai berikut:

1. Secara interaksi pemberian berbagai jenis pupuk cair pada berbagai varietas tanaman kacang hijau memberikan pengaruh terhadap tinggi tanaman dan umur berbungadengan perlakuan terbaik pemberian POMI $4 \mathrm{cc} / \mathrm{l}$ pada varietas Murai $\left(\mathrm{C}_{2} \mathrm{~V}_{4}\right)$.

2. Pengaruh utama jenis pupuk cair nyata terhadap parameter tinggi tanaman dan umur berbunga dengan perlakuan terbaik POMI $4 \mathrm{cc} / \mathrm{l}\left(\mathrm{C}_{2}\right)$.

3. Pengaruh utama jenis varietas nyata terhadap parameter tinggi tanaman dan umur berbungan dengan varietas terbaik adalah Kenari $\left(\mathrm{V}_{1}\right)$. 


\section{DAFTAR PUSTAKA}

Adisarwanto, T., 2005.Budidaya Kedelai dengan Pemupukan yang Efektif dan Pengoptimalan Peran Bintil Akar. Penebar Swadaya. Jakarta.104p.

Anonimus. 2012. Tinjauan Pustaka Kacang Hijau Varietas Vima-1. Diproleh dari http://www/usu.respository.ac.id.diakses pada 12 Maret 2016.

Hamli, F., Lapanjang, I.M., Dan Yusuf, R. 2015. "Respon Pertumbuhan Tanaman

Isroi. 2008. Pupuk kimia, pupuk organik dan pupuk hayati Http/:www.wordpress.com, 2008. Diakses pada tanggal 11 Juni 2016.

Mulyani, S. 2013. Pemberian Bokahi Bunga Jantan Kelapa Sawit dan TSP terhadap Pertumbuhan dan Produksi Tanaman Kacang Hijau (Vigna radiata L.) Skripsi (Tidak Dipublikasikan). Program Studi Agroteknologi Fakultas Pertanian. Universitas Islam Riau. Pekanbaru.

Munir, E. 2006. Pemanfaatan mikroba dalam bioremediasi: suatu teknologi alternatif untuk pelestarian lingkungan. Universitas Sumatera Utara, Medan.

Rinsema, 2004.Pupuk dan Cara Pemupukan. Penerbit Bhratara Karya Aksara. Jakarta.

Sawi (Brassica juncea L.)Secara Hidroponik Terhadap Komposisi Media Tanam Dan Konsentrasi Pupuk Organik Cair".Journal Agrotekbis Vol.3 No.3. Program Studi Agroteknologi, Fakultas Pertanian, Universitas Tadulako, Palu.
Suhartono. 2006. Manfaat dan Kandungan biji tanaman kacang hijau. Tanaman panganvarietas unggul. Penebar Swadaya. Jakarta.

Suryadi, R., Ghulamahdi, M., and Kurniawati, A. 2017.Nitrogen and Phosphorus Fertilization to Improve Growth, Seed Production and Thymoquinone Content of Black Cumin.Journal of Agronomy and Horticulture.IPB Bogor. 28 (1): 15-28.

Sutedjo. H. 2010. Petunjuk Penggunaan Pupuk.Penebar Swadaya. Jakarta

Sutedjo.M.M dan Sapoetra.A.G. 1987. Pengetahuan Ilmu Tanah. PT. Bina Angkasa. Jakarta.

Sutejo. 2002. Pupuk dan Cara Pemupukan. Rineka Cipta. Jakarta 